\title{
ИРАНО-ЕГИПЕТСКИЕ ОТНОШЕНИЯ И ВИЗИТ М. АХМАДИНЕЖАДА В КАИР В 2013 ГОДУ
}

В статье анализируются последствия падение проамериканского режима Хосни Мубарка в феврале 2011 г. в Египте, вследствие событий «Арабской весны», что поставило под угрозу всю систему безопасности в регионе Ближнего Востока. Приход к власти в 2012 г. исламиста Мухаммеда Мурси, открывал возможность для восстановления дипломатических отношений Египта и Ирана. Союз между двумя странами мог стать основой для новой расстановки сил в регионе. В центре внимания автора статьи - визит президента Ирана Махмуда Ахмадинежада в Каир в феврале 2013 г. Это был первый официальный визит такого уровня с момента победы Исламской революции в Иране и разрыва дипломатических отношений. В статье анализируются причины, планы и цели данного визита для официального Теге- рана. Характеризуется содержание основных встреч и двусторонних переговоров, как на официальном, так и на не официальном уровне. Показывается, что визит иранской делегации в Каир продемонстрировал наличие объективных причин, как внутреннего, так и внешнего характера, делавших невозможным завершение процесса восстановления полноформатных отношений между Ираном и Египтом на данном этапе времени. А военный переворот и свержение М. Мурси, вновь «заморозили» отношения между двумя странами на неопределенное время.

Ключевые слова: Арабская весна, Исламское пробуждение, Ближний Восток, Махмуд Ахмадинежад, Мухаммед Мурси.

\section{A. Baranov}

\section{IRANIAN-EGYPTIAN RELATIONS AND THE VISIT OF M. AHMADINEJAD TO CAIRO IN 2013}

The article analyzes the consequences of the fall of Hosni Mubarak's pro-American regime in February 2011 in Egypt, due to the events of the Arab Spring, which threatened the entire security system in the Middle East. The coming to power in 2012 of Islamist Mohammed Mursi opened the way for the restoration of diplomatic relations between Egypt and Iran. The union between the two countries could become the basis for a new alignment of forces in the region. The article focuses on the visit of Iranian President Mahmoud Ahmadinejad to Cairo in February 2013. It was the first official visit of this level since the victory of the Islamic Revolution in Iran and the severance of diplomatic

Избрание в июне 2012 г. в качестве президента Египта кандидата - исламиста в лице Мухаммеда Мурси, открывало широкие возможности по пересрорматированию региональной системы безопасности, которая и без того уже была подорвана эксцессами «Арабской весны». Эксперты с интересом и тревогой наблюдали за действиями нового президента Египта, выступившего за пересмотр внешнеполитического курса и провозгласившего необходимость восстановления разорванных отношений с Ираном. Действительно, на протяжении второй половины 2012 г. Мурси отметился целым рядом неординарных шагов на этом направлении, «пиком» которых явился визит в Тегеран на саммит Организации движения неприсоединения (ОДН) в конце августа 2012 г relations. The article analyzes the reasons, plans and goals of the visit for official Tehran. The study features the content of the main meetings and bilateral negotiations, both at the official and non-official levels. It is shown that the visit of the Iranian delegation to Cairo demonstrated the presence of objective reasons, both internal and external, which made it impossible to complete the process of restoring full-fledged relations between Iran and Egypt at that time. The military coup and the overthrow of M. Mursi, again "froze" the relations between the two countries for an indefinite time.

Key words: Arab Spring, Islamic Awakening, the Middle East, Mahmoud Ahmadinejad, Mohammed Mursi.

Начавшийся диалог в рамках «Исламского квартета» открывал возможность поиска компромисса по урегулированию сирийского кризиса силами региональных держав при активной поддержке со стороны Египта и Ирана. Выявившиеся спорные моменты во взаимоотношениях между Тегераном и Каиром требовали повторной встречи на высшем уровне лидеров двух стран. Такой возможностью и стал визит иранской правительственной делегации во главе с Махмудом Ахмадинежадом в Каир по приглашению его египетского коллеги в январе 2013 г. для участия в саммите Организации исламского сотрудничества (ОИС).

Для М. Ахмадинежада этот визит имел особый статус. Это был последний государственный ви- 
зит подобного уровня в ранге президента ИРИ так как в июне истекал его второй президентский срок. Следовательно, итоги этого визита должны были продемонстрировать возможности М. Ахмадинежада как дипломата и политика, не только регионального, но и мирового масштаба, а также жизнестойкость концепции «Исламского пробуждения». В этом отношении он и его администрация возлагали на саммит ОИС в Каире большие надежды.

За неделю до визита, М. Ахмадинежад дал большое интервью СМИ, на котором попытался осветить подходы по основным вопросам политики ИРИ в регионе. Он охарактеризовал позицию Ирана в отношении Сирии, Ирака и Палестины отметив, что Тегеран и Каир могут изменить баланс сил и геополитику региона, если они захотят этого. Для Тегерана, по словам М. Ахмадинежада, очень важно иметь стратегические отношения с Египтом как с влиятельной региональной державой. Одним из главных принципов внешнеполитической деятельности ИРИ является принцип невмешательства во внутренние дела региональных стран. Поэтому в отношении Сирии, Иран придерживается того подхода, что внутренние дела должен решать сам сирийский народ, без внешней интервенции. «Война - это не решение для Сирии, и сирийцы должны решать собственные проблемы через национальное согласие. Империализм же стремиться к расчленению стран региона» [1], уверен он. То же самое касается и Ирака, так как именно Запад уже долгое время сотрудничает с теми странами региона, которые добиваются расчленения Ирака. Иракский народ должен защитить свою страну через единение друг с другом. И Иран сделает все возможное со своей стороны, чтобы уменьшить степень напряжения в Ираке, и будет контактировать со всеми группами, чтобы добиться единства между ними.

Отдельно М. Ахмадинежад затронул вопрос Палестины и палестинского народа. «Поддержка Палестины - это основа стратегии ИРИ, и на протяжении многих лет после Революции, гуманитарная помощь собиралась для палестинцев на пятничных молитвах ежегодно», заявил он И если Египту и Ирану удастся консолидировать единую позицию в этом вопросе, то «политическая географрия региона измениться». Ахмадинежад даже признался, что хотел бы посетить Газу. «Если мне позволят сделать это, я поеду в Газу чтобы встретиться с народом», сказал он

Под конец своего интервью, президент остановился на активно муссируемым в западных СМИ мифе о существующем шиито суннитском противостоянии в регионе Ближнего Востока. По словам М. Ахмадинежада это искусственно создаваемый и реализуемый врагами исламского мира «новый план раскола», за которыми стоят «западные империалисты» во главе с США и их союзниками. Для Ирана нет принципиальной разницы в том, какая из стран региона подвергается агрессии, и страна будет помогать в ее отражении и Египту, и Саудовской Аравии. Важно, чтобы страны региона объединились, осознав реальность данной угрозы.

Сложность реализации данного подхода заключалась в стабильно ухудшающейся внутриполитической обстановке в Египте, что существенным образом отражалось на договороспособности Мохаммеда Мурси как президента и национального лидера. Страна все больше раскалывалась на сторонников и противников правительства. Новый всплеск массовых акций протеста пришелся на вторую годовщину начала египетской революции. Так получилось, что 25 января 2013 г. выпало на пятницу, и, после окончания пятничных молитв, страна погрузилась в хаос уличных беспорядков. Протестующие в Каире оккупировали Тахрир и ряд прилегающих улиц, а также мосты через Нил, парализовав движение в столице. Произошли столкновения с полицией, которая вынуждена была применять спецтехнику и слезоточивый газ для разгона протестующих. Накал уличных протестов не спадал и в период работы саммита ОИС в Каире. Это заставило принимающую сторону проводить все мероприятия вдали от центральных районов столицы. Заседания саммита проходили в пригороде Каира Аль-Тагаму аль-Хамис, в вдалеке от уличных столкновений протестующих с полицией. И в такой накаленной атмосфере политизированного египетского общества, Махмуд Ахмадинежад заявил по прибытии в Каир, что данная поездка «должна развеять пропагандистские и ментальные преграды на пути отношений между двумя великими народами Ирана и Египта» [2]. Задача как оказалось, была чрезвычайно ответственной и трудновыполнимой на практике.

О серьезности намерений иранской стороны может говорить представительный состав правительственной делегации. В нее вошли, помимо самого М. Ахмадинежада: советник президента и глава секретариата ОДН Эсфендияр Рахим-Машайе, глава Организации хаджа и паломничества Хассан Мусави, казначей и министр экономики Сейид Шамсуддин Хоссейни, министр разведки Хейдар Мослехи, министр нефти Ростам Кассеми глава МИД Али Акбар Салехи и многочисленные чиновники. А также очень плотный графрик встреч, официальных визитов и приемов. Естественно, что освещению хода визита уделялось пристальное внимание со стороны иранских СМИ.

Иранская делегация во главе с Махмудом Ахмадинежадом, прилетела в Каир 5 февраля 2013 г. В аэропорту их встречала египетская делегация во главе с М. Мурси. Торжественность церемонии придавал почетный военный караул и красная дорожка до здания аэропорта. В вип-зале для важных гостей, прошла первая встреча двух президентов. На встрече обе стороны выразили удовлетворения тем, что визит состоялся, а также прошел обмен мнениями по ситуации в регионе и в Сирии. В отношении последней стороны вновь подтвердили приверженность недопустимости вмешательства во внутренние дела Сирии извне.

Во второй половине того же дня состоялся один из важных моментов всего визита - прези- 
дент ИРИ посетил Аль-Азхар - ведущий богословский университет в исламском мире, пользующийся огромным уважением и влиянием среди мусульман-суннитов всего мира. Посещение и встреча с ведущими улемами во главе с шейхом Аль-Азхара Ахмедом аль-Тейбом, призвана была смягчить фрракционное напряжение в исламском мире между суннитами и шиитами. Это была первая встреча высокопоставленного иранского чиновника президентского уровня с главой религиозной власти Египта.

В ходе приема шейх Аль-Азхара заявил, что улемы уважают М. Ахмадинежада как личность, «стремящуюся работать на благо исламского единства». По уверению Ахмеда аль-Тейба, улемы Аль-Азхара стремятся бороться с проявлениями исламофобии, враждебностью в отношении шиитов, расхождениями во взглядах между различными мазхабами ислама. Шейх подчеркнул: «Даже если и возникают спорные моменты, то их необходимо разрешать мирно шиитам и суннитам" [3]. Ахмадинежад в ответ заявил, что влиятельные улемы Кума, Наджафа и Аль-Азхара должны в ходе совместных дискуссий, объединенными усилиями выработать общие критерии и стандарты, которые помогут человечеству спастись, возглавив объединительную миссию всех мусульман мира. Необходимо представить истинные ценности ислама миру, сказал президент ИРИ, чтобы установить справедливость во всем мире. В завершении он пригласил всех присутствующих посетить Иран.

По итогам встречи с улемами Аль-Азхара, М. Ахмадинежад сообщил на пресс-конференции, что ему удалось обсудить важные вопросы исламского мира и региона, «и по счастью обнаружились общие взгляды на необходимость реформы современной мировой ситуации. Мы согласились расширять научные и культурные связи" [4]. В целом, по словам президента, встреча прошла в теплой и дружественной обстановке.

После визита в Аль-Азхар М. Ахмадинежад, в сопровождении членов делегации, посетил мечеть Аль-Хуссейн, где принял участие в коллективной молитве, после которой пообщался с египтянами на улице перед мечетью. И как сообщали иранские СМИ, собравшиеся встречали президента с плакатами в руках, приветствуя на земле Египта.

Вечером, 5 феевраля, М. Ахмадинежад дал пресс-конференцию египетским журналистам, на которой охарактеризовал произошедшие за день события в ходе первого дня пребывания в стране. В ходе встречи, он заявил, что «египетский народ - это народ с богатой древней историей, которую мы все уважаем. Ваша земля - это земля культуры, цивилизации и гуманности». Он отметил роль Египта в развитии региона в прошлом и строительстве светлого будущего. «Два народа имеют много общего, даже в ощущении и восприятии региона и мира, что сближает нас друг с другом». Он охарактеризовал два народа, как двух братьев, которые вынуждены были расстаться на долгое время. «И если сегодня братья наконец-то воссоединяться и возьмутся рука об руку, то никакие козни со стороны надменных врагов не смогут сбить их с пути, так что это будет иметь положительное воздействие на скорейшие перемены в сторону справедливости и учета чаяний народов» [3].

В целом, согласно официальной версии, первый день прошел без серьезных эксцессов, и весьма удачно. Подводивший итоги глава иранской миссии интересов в Каире Моджтаба Амани, отверг просочившиеся в СМИ сообщения о якобы имевшихся проблемах. В частности Амани опроверг сообщения об имевшем место агрессивном действии толпы против кортежа президента ИРИ на подходе к мечети Аль-Хуссейн в Каире. По словам Амани народ скандировал лозунги в поддержку ирано египетских отношений, и никаких негативных акций в сторону президента не было. Это слухи, распространяемые недоброжелателями, чтобы омрачить визит [5].

Второй день пребывания иранской делегации был связан, главным образом, с участием в официальных мероприятиях 12-го саммита глав государств-членов ОИС. Помимо участия в официальной части, М. Ахмадинежад провел целый ряд двусторонних встреч на полях саммита с президентами Турции, Египта, Сенегала, Сомали, Судана, Боснии и Герцеговины, Коморских островов и главой ПНА Махмудом Аббасом. Также, в рамках саммита прошла отдельная трехсторонняя встреча президентов ИРИ, Турции и Египта, которые обменялись мнениями по урегулированию кризиса в Сирии. Было достигнуто предварительное соглашение с призывом к сторонам конфликта о немедленном прекращении насилия и кровопролития. Также договорились о созыве встречи на уровне глав МИД трех стран, которые должны будут обсудить конкретные предложения по плану урегулирования кризиса и представить окончательный согласованный вариант. Подводя итоги встречи, Ахмадинежад назвал ее «позитивной и конструктивной» [3].

Вечером в здании иранской миссии интересов М. Ахмадинежад встретился с главой Организации братьев-мусульман в Египте Мохаммедом Бадиа, и его помощниками - Мохаммедом Хайратом Саадом аль-Шатером и Иссамом Мохаммедом Хуссейном аль-Эрианом [6]. По сообщениям иранских СМИ, в ходе встречи стороны достигли соглашения о необходимости заключения пакта о стратегическом союзе между Египтом и Ираном. Ахмадинежад поздравил «Братьев» с победой на выборах и пригласил присутствующих лидеров движения посетить Иран и встретится с Рахбаром.

Бадиа, со своей стороны, приветствовал исламский строй Ирана, особенно деятельность Совета по определению целесообразности, который контролирует выработку стратегических и важнейших политических решений, выразив желание учредить подобный орган и в Египте. Лидер Братьев также приветствовал роль Ирана в организации сопротивления внешнему влиянию в 
регионе, заявив об успешности проводимой Ираном политики на протяжении последних тридцати лет. В особенности он высоко отозвался о практике Ирана по привлечению религиозных норм в управление государственными делами, считая это наиболее значимым достижением Исламской республики.

По окончании встречи состоялась пресс-конференция для египетских и иранских журналистов, на которой М. Ахмадинежад ответил на ряд вопросов касающихся Сирии, отношений Египта и Ирана, позиции Ирана в отношении Палестины и взаимоотношениях со странами Персидского залива [7]. Касательно урегулирования сирийского кризиса, М. Ахмадинежад подчеркнул неизменность позиции Ирана, основанной на праве сирийского народа самому решать свои внутренние дела, без внешнего вмешательства. В отношении Египта, позиция Тегерана также не изменилась Иран по-прежнему настаивает на восстановлении дипломатических связей, и инициатива теперь в руках египетских властей. В палестинском вопросе, иранский президент призвал к консолидации позиций двух стран, что приведет к разрешению проблемы к выгоде палестинского народа. Что же касается связей с монархиями Залива, по словам М. Ахмадинежада, «отношения Ирана со многими прибрежными государствами Персидского залива очень позитивны и конструктивны». Однако уверен он, Запад стремится все представить так, что существует напряжение и недовольство между странами. «Страны Залива - это братья и друзья, и у них нет недовольства друг другом». Запад стремится сохранить свое доминирование в регионе, так как он богат энергоресурсами. «Если мы сможем объединиться, им не удастся достичь своей цели», закончил Ахмадинежад

В последний день своего пребывания в Египте, М. Ахмадинежад потратил на культурную программу. «С разрешения иранских улемов мы посетили египетские пирамиды и Сфинкса» сообщил он уже после возвращения в Тегеран. «У Египта хорошее туристическое будущее для иранцев. К тому же египтяне очень набожный и дружелюбный народ» [2]. А вечером, 7 февраля иранский президент дал большое интервью египетскому телеканалу «Нил ТВ» [8], ответив на волнующие египтян вопросы в отношении Ирана, заявив об отсутствии «преград для возобновления нормальных отношений между Ираном и Египтом». Подчеркнув при этом стремление «Ирана сотрудничать с Египтом в атмосфере уважения и справедливости, мы не хотим навязывать какие-либо политические требования, развитие Египта - это наше развитие». Ахмадинежад признал, что не все в Египте хотят сближения с Ираном, но он уверен, что большинство египтян выступают за сотрудничество. «В Египте издаются тысячи газет, и если несколько из них выйдут с антииранскими заголовками, что это будет означать, что Египет выступает против Ирана?»

На следующий день, 8 февраля, иранская делегация во главе с М. Ахмадинежадом, отбыла на родину, завершив визит неофициальной встречей с бывшим генеральным секретарем ЛАГ и влиятельным политиком Амр Муссой.

Уже по прилету, в международном аэропорту Тегерана Мехрабад, М. Ахмадинежад попытался подвести первые итоги визита в Египет. Он кратко охарактеризовал свой визит в Каир как «особый» и «неповторимый», и поблагодарил Аллаха за то, что миссия иранского народа была выполнена. Далее М. Ахмадинежад выразил свое восхищение египетским народом: «Египетский народ набожный и дружелюбный. Везде где мы были, народ скандировал - Иран и Египет должны быть едины!» [2]. Он уверен, что в ходе визита, удалось многое сделать, чтобы развеять негативные клише в отношении Ирана и налаживании связей с Египтом, так как «те, кто пытался использовать различия и расстроить отношения между двумя странами, потерпел неудачу, и не смог добиться своих целей». В целом, иранский президент выразил удовлетворение итогами своего визита в Египет, обратив внимание на стремление и египетской стороны идти на налаживание отношений. «У нас оказался хороший настрой к сотрудничеству, и кажется, что позиции двух стран имеют много общих совпадений».

В знак доброй воли и намерений, Иран предложил ввести в одностороннем порядке безвизовый режим в начале для тех египетских граждан кто захочет посетить страну с туристическими целями. Далее планируется расширить действие этой программы на предпринимателей, студентов и религиозных деятелей. «Предложение оказалось эффективным, и весь мир увидит единение между народными массами двух стран», заявил М. Ахмадинежад. Также, по его словам, Иран, c целью облегчения финансового положения Египта, предложил обсудить вопрос об открытии кредитной линии для закупок в Иране товаров и услуг, что будет способствовать росту товарооборота между странами.

С оценкой визита, высказанной президентом солидаризировался и глава иранской миссии интересов в Каире Моджтаба Амани [9], назвавший визит Ахмадинежада “очень важным» в свете современной ситуации. Помимо присутствия на саммите, что явилось главным событием, президент совершил ряд запланированных заранее визитов. «Я уже долго нахожусь на службе в Египте, но такого теплого приема со стороны египтян, президента М. Мурси и их дружелюбная реакция по ходу визита превысила то, что я ожидал", признался Амани. Дипломат уверен, что народные приветствия и лозунги означают поддержку Ирана и исламского мира. В отношении встречи Президента с шейхами аль-Азхара, то он назвал ее «объединяющей и эффективной». Амани также прокомментировал отсутствие в визите посещения площади Тахрир в Каире. Он объяснил этот факт слишком плотным графиком визита, к тому же, по словам Амани, «Тахрир уже не является символом солидарности египтян, а скорее стал сценой политических конфликтов». 
Глава МИД ИРИ Али Акбар Салехи, комментируя итоги визита, был более сдержанным и менее оптимистичным [10]. Признавая за Ираном приоритетность налаживания отношений с Египтом, он заявил о наличии сильного сопротивления иранским инициативам. И это наблюдается не только внутри египетского общества, но и со стороны союзников Каира. Исходя из данного факта, он подчеркнул: «Мы должны сохранять бдительность в отношении заговоров, которые стоят на пути расширения ирано египетских отношений. Наши отношения очень важны, так что они не направлены против какой-либо страны». Также он обратил внимание на стремление противников сближения разжигать шиито суннитские разногласия, что призвано осложнить процесс налаживания двусторонних отношений между двумя крупнейшими державами региона - шиитским Ираном и суннитским Египтом. По словам А. Салехи это происходит из-за успехов в продвижении двух стран к консолидации.

В экспертных кругах Ирана превалировала критическая точка зрения на итоги визита, вплоть до его полного провала. Да, действительно, встреча в аэропорту вселяла надежду. Однако улучшений в отношении так и не произошло. Например, по мнению Надера Энтессара [11], показателен в этом отношении визит Ахмадинежада в Аль-Азхар, с точки зрения Египта, остающийся помехой на пути улучшения из-за суннито-шиитского раскола в ирано-египетских отношениях. Хотя для иранского президента визит в Аль-Азхар значил смягчение фракционного напряжения в исламском мире, он стал самым неудачным моментом пребывания Ахмадинежада в Египте. Шейх Aхмед аль-Тейб, Великий Имам мечети аль-Азхар, оказал холодный прием иранскому президенту. Хуже того, аль-Тейб публично унизил Ахмадинежада, не явившись на совместную пресс-конференцию, прислав вместо себя своего советника шейха Хассана аль-Шафийи, который начал провокационно и недружественно высказываться об иранской политике в Персидском заливе. Затем аль-Шафийи раскритиковал иранскую политику в отношении иранских арабов, живущих в Хузестане. Это было вопиющим вмешательством во внутренние дела Ирана, что могло привести к незамедлительному отьезду Ахмадинежада из Каира. Ведь аль-Шафийи делал свои заявления на официальном мероприятии как официальное, а не частное лицо.

По мнению Надера Энтессара, это может о3начать намеренную провокацию на ответные шаги со стороны Ирана, и тут возникает вопрос о возможностях Тегерана поступиться своими интересами ради номинального восстановления отношений с Египтом, тем более, если Каир не готов на взаимные уступки. Активно противодействовать также будут расхождение позиций по Сирии, возрождение и усиление влияния ваххабитов и салафитов, неопределенность внешнеполитического курса правительства М. Мурси, и сохраняющаяся зависимость от внешней помощи со стороны США и арабских монархий.
На сирийском треке, который должен был стать основой для консолидации и сближения политики двух стран, также не удалось достичь существенного прогресса. Планировалось, что именно урегулирование сирийского кризиса станет одной из важнейших тем, вынесенных на обсуждение саммита ОИС в Каире. Однако организаторы саммита, проходившего под лозунгом «Исламский мир: новые вызовы и растущие возможности», не внесли этот вопрос в официальную повестку. Согласно заявлению заместителя МИД АРЕ Амр Рамадана, повестка саммита охватывала пять тем: консрликты и споры в исламском мире; пути противостояния религиозной розни и исламофобии; гуманитарные вопросы исламского мира; экономическое и торговое сотрудничество между странами-членами; развитие научной и технической кооперации между исламскими странами Среди отдельных вопросов обсуждались конфоликт в Мали; мирный процесс в Судане (Суданом и Южным Суданом); ситуация в Сомали и в Афганистане. А это означало, что резолюции по Сирии согласовать не удалось, и она не вошла в окончательную Каирскую декларацию по итогам саммита ОИС

Показательным моментом является факт совпадения оценок иранских экспертов с оценками их египетских коллег. «Действительно ли сейчас правильное время для восстановления дипотношений с Ираном?», задается вопросом ведущая газета Египта «Аль-Ахрам» [12]. Визит М. Ахмадинежада выявил невозможность в данный период и данными участниками событий, говорить о восстановлении отношений между странами. И этому существуют серьезные причины. Во-первых, отношения Египта с Ираном сильно переплетены с отношениями Египта со странами Персидского залива. Во-вторых, Израиль и США также не примут быстрый пересмотр отношений Каира и Тегерана. "Для обоих государств, любое сближение с Ираном является красной линией, переступив которую, приведет к кардинальному пересрорматированию всего региона». В-третьих Тегеран активно поддерживает авторитарный сирийский режим. И как прокомментировал один анонимный источник из МИД Египта, режим Башара аль-Асада не соответствует духу революции в Египте и регионе: «Он напоминает народу режим Мубарака, против которого была начата революция». В качестве иллюстрации приводят инцидент с иранской делегацией при посещении мечети аль-Хуссейн, когда беженец из Сирии бросил туфлю в М. Ахмадинежада. В-четвертых, расцвет салафитского движения в Египте также не позволяет идти на восстановление отношений с Ираном, так как радикальные сунниты негативно воспринимают активизм шиитов в регионе, связывая его с Ираном.

Действительно крайне негативной реакции на визит иранской делегации со стороны салафитских партий Египта, наблюдатели уделили очень пристальное внимание. По признанию Мустафы аль-Лаббада, эксперта по Ирану и Турции, 
«превалировавшая при Мубараке иранофобия, продолжает сохраняться и при принятии государственной политики, сегодня» [13]

Подводя итог анализу реакции салафитских партий на инициативу Ирана восстановить отношения с Египтом, Абдель-Латиф Омайма [13] приходит к выводу, что реакция саласитов на визит Ахмадинежада и на политику Ирана диктуется теми, кто их спонсирует. А спонсоры находятся в монархиях Залива. Демонизация Ирана - это позиция просаудовских СМИ, которые финансируются саудовцами. На протяжении десятилетия саудовские шейхи вещали о шиитской угрозе а Иран долгое время замещал Израиль в качестве главного врага «номер один» для стран Залива. Салафиты, правда, не являются ключевой силой в формировании внешнеполитического курса Египта, но они, однако, способны мобилизовать общественное мнение, которое сможет оказать влияние на президента и соответствующие госорганы. В этом отношении, любой прогресс на треке Каир - Тегеран становиться заложником ответа со стороны салафитов.
Таким образом, визит иранской делегации в Каир продемонстрировал наличие объективных причин, как внутреннего, так и внешнего характеpa, делавших невозможным завершение процесса восстановления полноформатных отношений между Ираном и Египтом на данном этапе времени.

Падение проамериканского режима Хосни Мубарка в феврале 2011 г., вследствие «Арабской весны», поставило под угрозу всю систему безопасности в регионе Ближнего Востока. Приход к власти в 2012 г. исламиста Мухаммеда Мурси, открывало возможность установления дипломатических отношений Египта и Ирана. Союз между двумя странами мог стать основой для новой расстановки сил в регионе. В центре внимания автора статьи - визит президента Ирана Махмуда Ахмадинежада в Каир в феврале 2013 г. Визит иранской делегации в Каир продемонстрировал наличие объективных причин, как внутреннего, так и внешнего характера, делавших невозможным завершение процесса восстановления полноформатных отношений между Ираном и Египтом на данном этапе времени.

\section{Источники и литература / References}

1. Egypt and Iran can change 'regional balance': Ahmadinejad. URL: http://en.mehrnews.com/news/53951/Egypt-andIran-can-change-regional-balance-Ahmadinejad (Accessed: 05.02.2013).

2. Egyptians, pious and amicable: Ahmadinejad. URL: http://en.mehrnews.com/news/53995/Egyptians-pious-andamicable-Ahmadinejad (Accessed: 09.02.2013).

3. Ahmadinejad: Restoring ties with Iran Egyptian politicians' major concern. URL: http://www.irna.ir/en/News/80536017/ Politic/Ahmadinejad_Restoring_ties_with_Iran_Egyptian_politicians_major_concern (Accessed: 09.02.2013).

4. Egypt, Iran have 'common vision' to improve world: Sheikh of al-Azhar. URL: http://en.mehrnews.com/news/53965/ Egypt-Iran-have-common-vision-to-improve-world-Sheikh-of (Accessed: 06.02.2013).

5. Iranian envoy: No problem has arisen during President Ahmadinejad's Egypt visit. URL: http://www.irna.ir/en/ News/80533040/Politic//ranian_envoy_No_problem_has_arisen_during_President_Ahmadinejad_Egypt_visit (Accessed: 06.02.2013)

6. Muslim Brotherhood praises Iran's policies. URL: http://en.mehrnews.com/news/54046/Muslim-Brotherhood-praisesIran-s-policies (Accessed: 12.02.2013).

7. Iran will consider U.S. offer of talks if it sees positive changes. URL: http://en.mehrnews.com/news/53974//ran-willconsider-U-S-offer-of-talks-if-it-sees-positive-changes (Accessed: 07.02.2013).

8. Colonialism and mega-capitalism near collapse: Ahmadinejad. URL: http://en.mehrnews.com/news/53988/Colonialismand-mega-capitalism-near-collapse-Ahmadinejad (Accessed: 07.02.2013).

9. Why Ahmadinejad did not visit Tahrir Square. URL: http://en.mehrnews.com/news/54031/Why-Ahmadinejad-did-notvisit-Tahrir-Square (Accessed: 11.02.2013).

10. Iran-Egypt ties not against any country: FM. URL: http://www.irna.ir/en/News/80534621/Politic/lran-Egypt_ties_not_ against_any_country_FM (Accessed: 07.02.2013).

11. Entessar, Nader. 'There are areas where interests of Tehran and Cairo may intersect'. URL: http://en.mehrnews.com/ news/54214/There-are-areas-where-interests-of-Tehran-and-Cairo-may-intersect (Accessed: 22.02.2013).

12. El-Bey D. Conference diplomacy? // Al-Ahram Weekly. Cairo, 2013. №1135. 14 February. P. 2.

13. Omayma, Abdel-Latif. Paymaster politics. URL: http://weekly.ahram.org.eg/News/1427.aspx (Accessed: 14.02.2013)

\section{Сведения об авторе}

Баранов Алексей Владимирович - кандидат исторических наук, доцент кафедры всеобщей истории института истории и международных отношений Саратовского государственного университета, руководитель НОЦ «Востоковедения и иранистики» (Саратов) / baranovav@mail.ru

\section{Information about the author}

Baranov Alexey - PhD in History, Associate Professor, Chair of World history, Institute of History and International Relations, Saratov State University (Saratov) / baranovav@mail.ru 